\title{
Stav antropometrických parametrů a tělesného složení u studentů Vojenského oboru UK FTVS v Praze
}

\section{Status anthropometric parameters and body composition of students of the Military Department at UK FTVS in Prague}

\author{
Ivana Kinkorová, Matěj Vrba
}

Fakulta tělesné výchovy a sportu Univerzity Karlovy, Praha, Česká republika

\begin{abstract}
Abstrakt
Cílem našeho sledováníbylo měření vybraných antropometrických charakteristik, resp. stanovení somatotypu, analýza aktuálního tělesného složení u studentů Vojenského oboru (VO) UK FTVS v Praze a srovnánís obdobnými studiemi. Soubor tvořilo celkem 22 probandů, muži ve věkovém rozmezí 19-27 let (průmérný věk $=22,9 \pm 2,6$ let, tělesná výška $=179,9 \pm 6,0 \mathrm{~cm}$, tělesná hmotnost $=76,8 \pm 7,0 \mathrm{~kg}, \mathrm{BMI}=$ $\left.23,8 \pm 1,5 \mathrm{~kg} \cdot \mathrm{m}^{-2}\right)$.Z hlediska zjištěného průměrného somatotypu $(1,7-7,3-2,5)$ mají studenti VO velmi dobré předpoklady k všeobecné tělesné výkonnosti. Kanalýze tělesného složení byla použita BIA-Tanita MC 980 (celotělová a segmentální analýza). Studenti VO vykazovali vysoký podíl tukuprosté hmoty $(70,5 \pm 6,1 \mathrm{~kg})$ a nízké zastoupení tělesného tuku $(8,3 \pm 3,0 \%)$. Autoři zdůrazňují dưležitost sledování i dalších parametrů tělesného složení, např. celková tělesná voda (TBW), extracelulární voda (ECW), intracelulární voda (ICW), segmentální analýza svalové hmoty a tělesného tuku.
\end{abstract}

\begin{abstract}
The aim of our study was the measurement of selected anthropometric variables, respectively determining somatotype, body composition analysis of students Military Department (MD) at UK FTVS in Prague and compared to similar studies. The group consisted of 22 probands, men ranging in age from $19-27$ years (mean age $=22,9 \pm 2,6$ years, height $=179,9 \pm 6,0 \mathrm{~cm}$, weight $=76,8 \pm 7,0 \mathrm{~kg}, \mathrm{BMI}=23,8 \pm$ $\left.1,5 \mathrm{~kg} \cdot \mathrm{m}^{-2}\right)$. In terms of measured average somatotype $(1,7-7,3-2,5)$, the students MD have very good preconditions for general physical fitness. We used BIA-Tanita MC 980 for the body composition analysis (whole body and segmental analysis). The students MD showed a high proportion of lean body mass $(70,5 \pm 6,1 \mathrm{~kg})$ and low proportion of fat mass $(8,3 \pm 3,0 \%)$. The authors emphasize the importance of monitoring and other parameters of body composition, e.g. total body water (TBW), extracellular water (ECW), intracellular water (ICW), segmental analysis of muscle mass and body fat.
\end{abstract}

Klíčová slova: antropometrie, somatotyp, bioelektrická impedance, tělesné složení, vojenská tělovýchova.

Keywords: anthropometry, somatotype, bioelectrical impedance, body composition, military physical training.

Tato studie vznikla s podporou projektu PRVOUK P38 a za podpory SVV 2015-260236.

\section{ÚVOD}

Studenti Vojenského oboru (VO) při UK FTVS v Praze tvoří specifickou skupinu v rámci tělovýchovného vzdělávání. Mají možnost získat nejvyšší tělovýchovné vzdělání se specializací na ozbrojené složky České republiky. Náplní jejich budoucího zaměstnání je komplexní péče o vojáky $\mathrm{v}$ rámci speciální a základní tělesné přípravy, např. příprava vojáků ke každoročnímu přezkoušení z tělesné př́ipravy (Normativní výnos MO 12/2011), organizace sportovních dnů 
a armádních závodů, případně možnost zúčastnit se zahraničních misí. Studenti VO musí splňovat určité funkční předpoklady, protože nároky na ně kladené jsou vyšší než na studenty běžných civilních tělovýchovných oborů (např. obor Tělesná výchova a sport, Management sportu apod.). V rámci studia musí absolvovat i další nadstavbové aktivity (např. kurzy přežití, vojenského lezení, přesunů na ledu a sněhu a další). Na rozdíl od civilisty je voják z povolání vázán dodržováním zákona 221/1999 Sb., kde jsou v §48 uvedeny základní povinnosti vojáků. Jednou ze základních povinností vojáka je dbát o svou fyzickou zdatnost. Tělesná zdatnost a zdraví jedince vždy byly a stále jsou hlavními znaky bojeschopného vojáka. Z historie víme, že vojáci museli být fyzicky velice zdatní, aby zvládali nejen náročný výcvik, ale mohli i překonávat chůzí obrovské vzdálenosti, boj trvající mnohdy několik dní, případně extrémní klimatické podmínky. Organizace a struktura moderní Armády České Republiky (AČR) zahrnuje několik úrovní složek (velitelství a štáb, brigády, prapory, zdravotnické celky, vojenské školy, vědu a výzkum apod.), přičemž každá z těchto složek má jiné úkoly a povinnosti v rámci komplexnosti celé AČR. Z toho vyplývá, že pro každou pracovní pozici jsou prioritní jiné požadavky. Důsledkem toho mohou být veliké rozdíly ve fyzické a psychické připravenosti jednotlivých vojáků. Od roku 1999 je v AČR realizován program rozšířené preventivní péče - každoroční prohlídky vojáků z povolání (VZP) nejrůznějších vojenských profesí, funkcí a vzdělání v jednotlivých věkových kategoriích. U jedinců běžné populace se neustále zvyšuje především riziko výskytu kardiovaskulárních onemocnění (ateroskleróza, hypertenze, ischemická choroba srdeční (ICHS), mozková mrtvice), vysoké hladiny triglyceridů (TG) a LDL cholesterolu v krvi, postprandiální hyperinzulinémie a sacharidové intolerance, diabetes mellitus II. typu, osteoporózy, zhoubných novotvarů, deprese (Wei et al., 1999; Bunc, 2007). Bohužel výsledkové hodnoty antropometrických a biochemických parametrů zjištěné při každoročních zdravotních prohlídkách vojáků z povolání výskyt těchto neinfekčních onemocnění do značné míry kopírují. Právě tato onemocnění patří $\mathrm{k}$ nejčastějším příčinám dočasné nebo trvalé neschopnosti služby v posledních letech u př́slušníků AČR. Analýza četnosti výskytu ovlivnitelných i neovlivnitelných rizikových faktorů predikujících vznik a rozvoj těchto onemocnění představuje základní předpoklad úspěšného ovlivňování morbidity i mortality na uvedené nemoci mezi př́slušníky AČR i běžné české populace (Střítecká \& Hlúbik, 2009; Pavlík a kol., 2011). Vztah rizikových faktorů a výskyt výše zmiňovaných onemocnění, ale i případný vliv nedostatečné fyzické aktivity a nadměrného celkového energetického př́ijmu, které ve svém důsledku zvyšují výskyt nadváhy a obezity, resp. přispívají k rozvoji celé řady závažných zdravotních, klinických a ekonomických problémů, byl a stále je předmětem řady studií. Danou problematikou u př́slušníků Armády ČR se ve svých studiích zabývali např. Hlúbik \& Střítecká, 2007; Střítecká \& Hlúbik, 2009; Pavlík a kol., 2011. Dlouhodobým monitorováním aktuálního tělesného stavu populace s důrazem na př́islušníky AČR a porovnáním tělesných parametrů příslušníků bojových a nebojových jednotek AČR se zabývali Soumar \& Oberman (2010). Práce Štěpničky (1979) publikuje výsledky 543 mužů - studentů tělesné výchovy UK FTVS v Praze v letech 1969-1975. Řada studií byla zaměřena i na hodnocení somatotypu vojenských studentů (Ebner, 2008) nebo určením a porovnáním tělesného složení slovenských studentů vojenské akademie, polských studentů a studentů FTK Olomouc (Mašková, 2009).

V praxi existuje celá řada jednoduchých měřitelných ukazatelů (BMI, obvod pasu, obvod boků, WHR index atd.), které lze použít identifikaci kardiovaskulárních rizikových faktorů nebo pro posouzení aktuálního tělesného stavu jedince, nicméně jejich použitelnost a prezentace v praxi je mnohdy sporná. Vezmeme-li např. BMI (Body mass index), který se řadí mezi kvantitativní klinické ukazatele složení těla. Tento tzv. hmotnostně-výškový index pouze zhodnotí, zda daný jedinec hmotnostně odpovídá populačním normám, nikoliv jaké je jeho složení těla, tj. podíl jednotlivých komponent především ve smyslu množství tělesného tuku a tukuprosté hmoty, množství celkové tělesné vody a jejich jednotlivých frakcí apod., případně segmentální rozložení těchto komponent (Andreoli et al., 2003). Současné složitější a podrobnější metodiky hodnotící tělesné složení se vzájemně liší nejen přístrojovou a personální náročností, ale i možnostmi interpretace a přesností 
sledovaných dat, což jsou nejvýznamnější faktory limitující jejich použití v různých podmínkách (Dlouhá a kol., 1998; Bunc, 2007).

Znalost aktuálního tělesného složení a somatotypu může mimo jiné přispět k posouzení zdravotního stavu jedince, $\mathrm{k}$ posouzení jeho fyzické připravenosti, ale může být zohledněna i např. při tvorbě odpovídajících cvičebních programů pro studenty VO.

Cílem našeho sledování bylo měření vybraných antropometrických charakteristik, resp. stanovení somatotypu, analýza aktuálního tělesného složení u studentů Vojenského oboru (VO) UK FTVS a následně porovnání s výsledky podobných studií. Vzhledem k požadavkům a nárokům, které jsou kladeny na studenty VO, resp. na vojáky z povolání, předpokládáme, že hodnoty BMI $\left(\mathrm{kg} / \mathrm{m}^{2}\right)$ se budou pohybovat v optimálním rozmezí BMI podle WHO (2015), dominanci mezomorfní komponenty v somatotypech jednotlivých probandů, vyšší podíl tukuprosté hmoty, nízké zastoupení tukové tkáně a vyšší zastoupení celkové tělesné vody (TBW), která je v organismu vázána především ve svalové hmotě.

\section{METODIKA}

\section{Soubor}

Sledovaný soubor tvořili studenti VO $(n=22)$ navštěvující prezenční formu studia na UK FTVS v Praze ve věkovém rozmezí 19-27 let (průměrný věk - 22,9 \pm 2 ,6let, tělesná výška $179,9 \pm 6,0 \mathrm{~cm}$, tělesná hmotnost $\left.-76,8 \pm 7,0 \mathrm{~kg}, \mathrm{BMI}-23,8 \pm 1,5 \mathrm{~kg} \cdot \mathrm{m}^{-2}\right)$. Testování proběhlo se souhlasem Etické komise UK FTVS. Probandi byli seznámeni s cílem a průběhem celého testování a podepsali informovaný souhlas. Měření proběhlo jednorázově v prostorách Biomedicínské laboratoře UK FTVS. Měřní antropometrických parametrů a obsluhu přístroje BIA (Tanita MC-980) prováděla jedna osoba z důvodu minimalizace chyby. Při sběru všech dat byly zajištěny stejné objektivní podmínky.

\section{Použité metody}

Ze základních antropometrických parametrů byly měřeny tělesná výška $(\mathrm{cm})$ a tělesná hmotnost $(\mathrm{kg})$. Tělesná výška $(\mathrm{cm})$ byla stanovena pomocí antropometru s přesností na $0,1 \mathrm{~cm}$. Tělesná hmotnost (kg) byla měřena pomocí digitální váhy s přesností na $0,1 \mathrm{~kg}$. Obvodové míry (obvod paže v kontrakci, obvod lýtka) byly stanoveny použitím neelastického pásma (šířka $0,7 \mathrm{~cm}$ ) s přesností na $0,1 \mathrm{~cm}$. Šiŕkové rozměry ( šiřka epikondylů humeru, šiřka epikondylů femuru) byly stanoveny pomocí antropometrického měřítka s přesností na $0,5 \mathrm{~mm}$. Pro měření tlouštiky kožních řas (triceps, scapula, spina, lýtko) byl použit kaliper Harpendenského typu, u kterého je tlak na kožní řasu $10,0 \mathrm{~g} / \mathrm{mm}^{2}$. Kožní řasy byly měřeny na pravé straně těla s přesností na $0,1 \mathrm{~cm}$.

Byl stanoven index BMI $\left(\mathrm{kg}^{\mathrm{m}} \mathrm{m}^{-2}\right)$, hodnocen podle norem WHO (2015). Somatotyp byl stanoven podle Heathové a Cartera (1967) za pomoci programu Somatotype 1.2.5 (dostupné z: http:// goulding.ws/somatotype/).

K analýze tělesného složení byl použit multifrekvenční přístroj BIA (Tanita MC-980) (Biospace Co.), který pracuje s frekvencemi $1,5,50,250,500,1000 \mathrm{kHz}$ a umožñuje celotělovou a segmentární analýzu tělesného složení. Sledovány byly především následující parametry: tělesný tuk (FM), tukuprostá hmota (FFM), celková tělesná voda (TBW), extracelulární (ECW) a intracelulární (ECW) voda, segmentální analýza tukuprosté hmoty a tělesného tuku. Tělesné složení bylo vyhodnoceno pomocí softwaru přístroje (Tanita MC-980) za použití predikčních rovnic pro sportující populaci (režim Athletic).

\section{Statistické zpracování}

K analýze dat a jejich statistickému zpracování jsme použili programy SPSS a Microsoft Excel. Pro popis souboru byly využity základní statistické charakteristiky (aritmetický průměr, směrodatná odchylka, min a max hodnoty).

Pro zhodnocení významnosti rozdílů mezi párovými horními a dolními končetinami jsme použili parametrický t-test, významnost rozdílu byla posuzována na hladině významnosti $\alpha=0,05$. Pro 
posouzení míry věcné významnosti rozdílů byl použit koeficient $\omega^{2}$ (Haysovo omega ${ }^{2}$ ). Za věcně významný rozdíl jsme považovali hodnoty $\omega^{2} \geq 0,1$ (Sigmundová \& Sigmund, 2012).

\section{Výsledky}

Průměrné hodnoty základních antropometrických charakteristik (Tab. 1) a jednotlivých parametrů z analýzy tělesného složení BIA (Tanita MC 980) (Tab. 2) jsou uvedeny tabulkově. Graficky (Obr. 1) jsou znázorněny somatotypy jednotlivých studentů a průměrný somatotyp celého souboru souboru.

Tab. 1: Základních antropometrické charakteristiky studentů VO $(n=22)$ (hodnoty jsou uvedeny ve tvaru aritmetický průměr \pm směrodatná odchylka, min-max hodnota).

\begin{tabular}{|c|c|c|c|}
\hline & & průměr $\pm \mathrm{SD}$ & $\min -\max$ \\
\hline \multicolumn{2}{|c|}{ Věk (let) } & $22,9 \pm 2,6$ & $19-29$ \\
\hline \multicolumn{2}{|c|}{ Tělesná hmotnost (kg) } & $76,8 \pm 7,0$ & $61,6-90,0$ \\
\hline \multicolumn{2}{|c|}{ Tělesná výška $(\mathrm{cm})$} & $179,9 \pm 6,0$ & $166,3-191,6$ \\
\hline \multicolumn{2}{|c|}{ BMI $\left(\mathrm{kg} / \mathrm{m}^{2}\right)$} & $23,8 \pm 1,5$ & $20,8-26,2$ \\
\hline \multirow{2}{*}{ Obvodové rozměry $(\mathrm{cm})$} & paže (v kontrakci) & $35,9 \pm 1,7$ & $32,0-41,0$ \\
\hline & lýtko & $37,9 \pm 1,7$ & $36,0-43,0$ \\
\hline \multirow{2}{*}{ Šířkové rozměry (mm) } & epicondyly humeru & $91,1 \pm 4,0$ & $81,0-102,0$ \\
\hline & epicondyly femuru & $102,1 \pm 4,7$ & $90,0-110,0$ \\
\hline \multirow{4}{*}{ Kožní řasy (mm) } & triceps & $5,9 \pm 1,6$ & $4,0-10,0$ \\
\hline & scapula & $8,9 \pm 1,0$ & $7,0-11,0$ \\
\hline & spina & $4,5 \pm 0,9$ & $3,0-6,0$ \\
\hline & lýtko & $5,0 \pm 1,1$ & $4,0-8,0$ \\
\hline \multirow{3}{*}{$\begin{array}{l}\text { Komponenty } \\
\text { somatotypu }\end{array}$} & endomorf & $1,7 \pm 0,3$ & $1,2-2,4$ \\
\hline & mezomorf & $7,3 \pm 0,8$ & $6,2-9,0$ \\
\hline & ektomorf & $2,5 \pm 0,8$ & $1,0-4,1$ \\
\hline
\end{tabular}

Průměrná hodnota BMI $\left(\mathrm{kg} \cdot \mathrm{m}^{-2}\right)$ sledovaného souboru 23,8 $\pm 1,5 \mathrm{~kg} \cdot \mathrm{m}^{-2}$ odpovídá doporučenému rozmezí pro optimální tělesnou hmotnost u běžné populace $\left(\mathrm{BMI}=18,5-24,9 \mathrm{~kg} \cdot \mathrm{m}^{-2}\right.$, WHO, 2015). Při individuálním hodnocení jednotlivých probandů spadalo 16 probandů $(72,7 \%)$ do normálního rozmezí pro hodnocení tělesné hmotnosti $\left(\mathrm{BMI}=18,5-24,9 \mathrm{~kg} / \mathrm{m}^{2}\right), 6$ probandů $(27,3 \%)$ se řadilo do kategorie nadváhy $\left(B M I=25,0-29,9 \mathrm{~kg} / \mathrm{m}^{2}\right)$. 


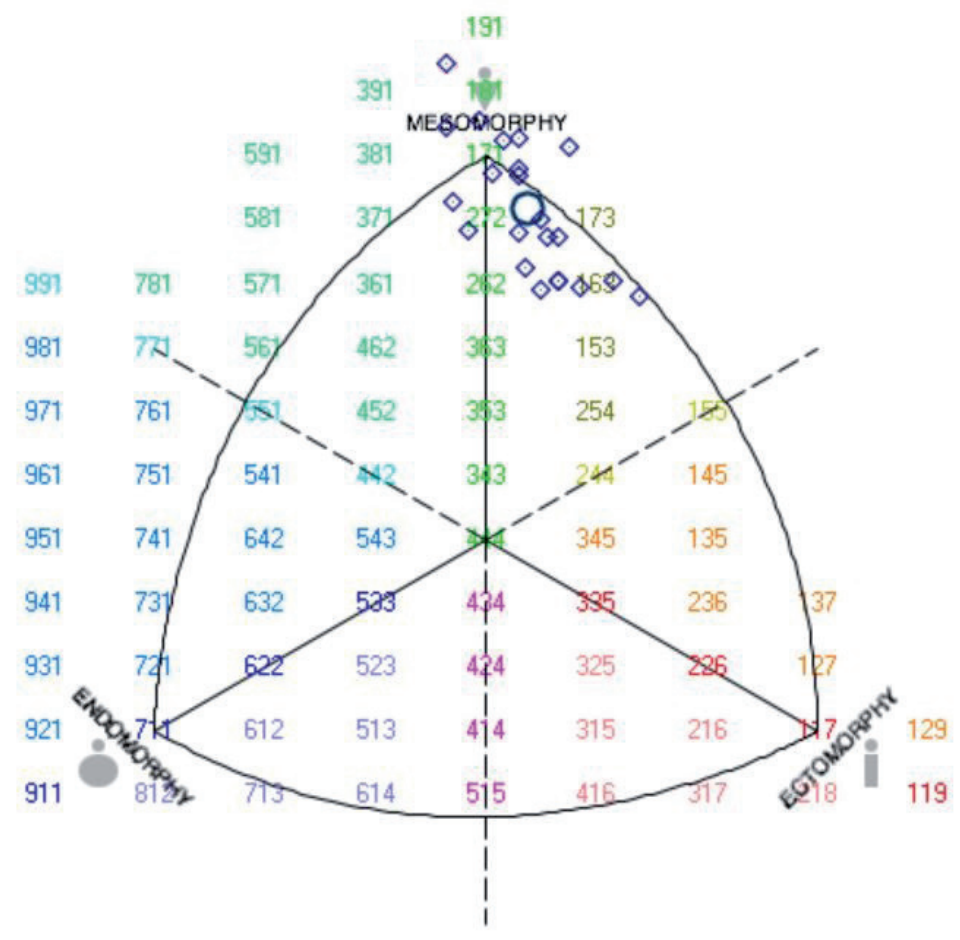

Obr. 1: Somatograf s jednotlivými somatotypy studentů VO $(n=22)$ a průměrným somatotypem souboru

Legenda: $\diamond$ somatotypy studentů $\mathrm{VO}, \bigcirc$ průměrný somatotyp souboru

Průměrný somatotyp studentů VO byl charakterizovaný trojčíslím 1,7-7,3-2,5, tj. ektomorfní mezomorf. Rozmístění somatotypů na somatografu (Obr. 1) ukazuje, že většina studentů VO, tj. 15 probandů $(68,2 \%)$ bylo vyhodnoceno jako ektomorfní mezomorf, tj. s dominancí druhé mezomorfní komponenty a vyšší třetí ektomorfní komponentou než první endomorfní komponentou. 3 studenti VO (13,6\%) byli popsáni jako endomorfní mezomorf, tj. druhá mezomorfní komponenta dominantní, ale první endomorfní je vyšší než třetí ektomorfní. Zbývající 4 probandi (18,2 \%) byli vyhodnoceni jako vyrovnaný mezomorf, tj. druhá složka dominantní, první endomorfní a třetí ektomorfní komponenta nižší. 
Tab. 2: Průměrné hodnoty jednotlivých parametrů $z$ analýzy tělesného složení BIA (Tanita $M C$ 980) studentů VO $(n=22)$ (hodnoty jsou uvedeny ve tvaru aritmetický průměr \pm směrodatná odchylka, min-max hodnota)

\begin{tabular}{|c|c|c|c|c|}
\hline & & & průměr \pm SD & $\min -\max$ \\
\hline \multirow{8}{*}{ Celotělová analýza } & \multicolumn{2}{|c|}{ FM (\%) } & $8,3 \pm 3,0$ & $4,1-15,4$ \\
\hline & \multicolumn{2}{|c|}{$\mathrm{FM}(\mathrm{kg})$} & $6,5 \pm 2,5$ & $2,9-12,4$ \\
\hline & \multicolumn{2}{|c|}{ FFM (kg) } & $70,5 \pm 6,1$ & $56,2-84,4$ \\
\hline & \multicolumn{2}{|c|}{ TBW (\%) } & $66,5 \pm 2,9$ & $59,7-72,1$ \\
\hline & \multicolumn{2}{|c|}{ TBW (kg) } & $51,2 \pm 4,8$ & $40,6-64,3$ \\
\hline & \multicolumn{2}{|c|}{ ICW $(\mathrm{kg})$} & $33,9 \pm 4,1$ & $25,5-45,6$ \\
\hline & \multicolumn{2}{|c|}{$\mathrm{ECW}(\mathrm{kg})$} & $17,3 \pm 0,9$ & $15,1-18,9$ \\
\hline & \multicolumn{2}{|c|}{ ECW/TBW (\%) } & $33,9 \pm 1,8$ & $29,1-37,8$ \\
\hline \multirow{10}{*}{ Segmentární analýza } & \multirow{5}{*}{ Svalová hmota (kg) } & PHK & $4,34 \pm 0,5$ & $3,2-5,7$ \\
\hline & & LHK & $4,26 \pm 0,5$ & $3,2-5,2$ \\
\hline & & Trup & $35,86 \pm 2,9$ & $29,1-42,6$ \\
\hline & & PDK & $11,40 \pm 1,0$ & $9,1-13,5$ \\
\hline & & LDK & $11,30 \pm 1,0$ & $8,8-13,3$ \\
\hline & \multirow{5}{*}{ Tělesný tuk (\%) } & PHK & $6,85 \pm 1,7$ & $2,6-10,1$ \\
\hline & & LHK & $7,10 \pm 2,2$ & $2,1-11,4$ \\
\hline & & Trup & $7,17 \pm 3,9$ & $3,0-16,3$ \\
\hline & & PDK & $9,60 \pm 2,2$ & $6,1-13,9$ \\
\hline & & LDK & $9,91 \pm 2,3$ & $4,8-13,9$ \\
\hline
\end{tabular}

Legenda: FM - tuková hmota (\%, kg), FFM - tukuprostá hmota $(\mathrm{kg})$, TBW - celková tělesná voda $(\mathrm{kg}, \%)$, ICW - intracelulární voda $(\mathrm{kg}), \mathrm{ECW}$ - extracelulární voda $(\mathrm{kg})$, poměr ECW/TBW - index retence vody, ukazatel otoků (\%), LHK - levá horní končetina, LDK - levá dolní končetina, PHK - pravá horní končetina, PDK - pravá dolní končetina

Zjištěná průměrná hodnota tělesného tuku (FM) u studentů VO byla poměrně nízká $8,3 \pm 3,0 \%$, což odpovídá $6,5 \pm 2,5 \mathrm{~kg}$ z celkové průměrné hmotnosti. Průměrná hodnota TBW u probandů byla $66,5 \pm 2,9 \%$, tj. $51,2 \pm 4,8 \mathrm{~kg}$, přičemž ICW tvořila $33,9 \pm 4,1 \mathrm{~kg}$ a ECW $17,3 \pm 0,9 \mathrm{~kg}$. Průměrná hodnota poměru ECW/TBW (index retence vody) u sledovaného souboru byla 33,9 \pm 1,8\%. Rozmezí hodnot ECW/TBW se pohybovalo 29,1-37,8\%, tj. u žádného $\mathrm{z}$ probandů nebyl zaznamenán případný problém s retencí vody v organismu. Fyziologicky by se hodnota ECW/TBW měla pohybovat do $45 \%$.

Segmentární analýza tělesného složení, resp. rozložení svalové hmoty $(\mathrm{kg})$ a tělesného tuku (\%) na jednotlivých segmentech těla (trup, pravá paže, levá paže, pravá noha, levá noha) je uvedena v Tab. 2.

Všech 22 probandů (tj. $100 \%$ probandů) uvedlo dominantní PHK. Dominanci PDK uvedlo 17 probandů (tj. $77 \%$ probandů) a dominanci LDK 5 probandů (tj. $23 \%$ probandů). Při sledování rozložení svalové hmoty $(\mathrm{kg})$ na horních končetinách jsme zaznamenali průměrné hodnoty na $\mathrm{PHK}=4,34 \pm 0,5 \mathrm{~kg}$ a na $\mathrm{LHK}=4,26 \pm 0,5 \mathrm{~kg}$, tj. průměrný rozdíl $0,08 \mathrm{~kg}$, rozdíl byl statisticky $\left(\mathrm{t}_{21}=2,057 ; \mathrm{p}<0,05\right)$ i věcně $\left(\omega^{2}=0,13\right)$ významný. Na dolních končetinách jsme zjistili průměrné hodnoty na $\mathrm{PDK}=11,40 \pm 1,0 \mathrm{~kg}$ a na $\mathrm{LDK}=11,30 \pm 1,0 \mathrm{~kg}$, tj. průměrný rozdíl $0,1 \mathrm{~kg}$, rozdíl byl statisticky $\left(\mathrm{t}_{21}=4,062 ; \mathrm{p}<0,05\right)$ i věcně $\left(\omega^{2}=0,40\right)$ významný.

Při sledování rozložení tělesného tuku (\%) na horních končetinách jsme zaznamenali průměrné hodnoty na $\mathrm{PHK}=6,85 \pm 1,7 \%$ a na $\mathrm{LHK}=7,10 \pm 2,2 \%$, tj. průměrný rozdíl $0,25 \%$, rozdíl nebyl statisticky $\left(\mathrm{t}_{21}=1,161 ; \mathrm{p}>0,05\right)$ ani věcně $\left(\omega^{2}=0,02\right)$ významný. Na dolních končetinách jsme 
zjistili průměrné hodnoty na $\mathrm{PDK}=9,60 \pm 2,2 \%$ a na $\mathrm{LDK}=9,91 \pm 2,3 \mathrm{~kg}$, tj. průměrný rozdíl $0,31 \%$, rozdíl byl statisticky $\left(\mathrm{t}_{21}=2,071 ; \mathrm{p}<0,05\right)$ i věcně $\left(\omega^{2}=0,13\right)$ významný.

\section{DISKUSE}

Sledování řady antropometrických parametrů a analýza tělesného složení, resp. zastoupení a vztah jednotlivých komponent tělesného složení, mohou být vhodným ukazatelem nejen nutričního stavu jedince, ale také ukazatelem vlivu pohybové aktivity na organismus.

V naměřených hodnotách tělesné výšky $(\mathrm{cm})$ a tělesné hmotnosti $(\mathrm{kg})$ u jednotlivých probandů sledovaného souboru (studentů VO) byly patrné značné rozdíly. Průměrná tělesná výška probandů byla 179,9 $\pm 6,0 \mathrm{~cm}$ (rozmezí 166,3-191,6 cm, rozdíl 25,3 cm), průměrná tělesná hmotnost byla $76,8 \pm 7,0 \mathrm{~kg}$ (rozmezí $61,6-90,0 \mathrm{~kg}$, rozdíl $28,4 \mathrm{~kg}$ ). Hodnoty průměrné tělesné výšky $(\mathrm{cm})$ a průměrné tělesné hmotnosti $(\mathrm{kg})$ v podstatě odpovídají hodnotám podle Bláhy (1987), který uvádí průměrnou tělesnou výšku dospělé mužské populace $178,0 \mathrm{~cm}$ a průměrnou hmotnost $74,0 \mathrm{~kg}$. Z hlediska normativních hodnot BMI podle WHO (2015) spadalo 16 probandů $(72,7 \%)$ do normálního rozmezí pro hodnocení tělesné hmotnosti $\left(\mathrm{BMI}=18,5-24,9 \mathrm{~kg} / \mathrm{m}^{2}\right), 6$ probandů $(27,3 \%)$ se řadilo do kategorie nadváhy $\left(B M I=25,0-29,9 \mathrm{~kg} / \mathrm{m}^{2}\right)$, což mohlo být způsobeno např. vyšším zastoupením tukuprosté hmoty.

Podobným srovnáním antropometrických parametrů a parametrů tělesného složení se zabývali např. Mašková (2009), Soumar \& Oberman (2010), Komár (2012) a další. Porovnání s výsledky jiných studií je uvedeno v Tab. 3.

Tab. 3: Srovnání jednotlivých parametrů probandů VO s dalšími studiemi (hodnoty jsou uvedeny ve tvaru aritmetický průměr \pm směrodatná odchylka)

\begin{tabular}{|c|c|c|c|c|c|c|}
\hline Studie & Soubor & $\mathbf{n}$ & $\begin{array}{l}\text { Tělesná v́šška } \\
\text { (cm) }\end{array}$ & $\begin{array}{c}\text { Tělesná } \\
\text { hmotnost (kg) }\end{array}$ & BMI $\left(\mathrm{kg} / \mathrm{m}^{2}\right)$ & $\begin{array}{c}\text { Tuk (\%) } \\
\text { (metodika) }\end{array}$ \\
\hline $\begin{array}{l}\text { Současná } \\
\text { studie }\end{array}$ & $\begin{array}{l}\text { Studenti VO } \\
\text { UK FTVS }\end{array}$ & 22 & $179,9 \pm 6,0$ & $76,8 \pm 7,0$ & $23,8 \pm 1,5$ & $\begin{array}{c}8,3 \pm 3,0 \\
\text { (BIA) }\end{array}$ \\
\hline \multirow{3}{*}{$\begin{array}{l}\text { Mašková } \\
\text { (2009) }\end{array}$} & $\begin{array}{l}\text { Studenti FTK } \\
\text { Olomouc }\end{array}$ & 135 & $180,4 \pm 5,8$ & $75,2 \pm 7,5$ & $23,1 \pm 1,9$ & $\begin{array}{c}10,0 \pm 3,8 \\
(\mathrm{BIA})\end{array}$ \\
\hline & $\begin{array}{c}\text { Studenti TVS } \\
\text { (Polsko) }\end{array}$ & 18 & $182,5 \pm 5,3$ & $80,3 \pm 9,8$ & $24,1 \pm 7,5$ & $\begin{array}{c}9,1 \pm 3,0 \\
\text { (BIA) }\end{array}$ \\
\hline & $\begin{array}{l}\text { Studenti VO } \\
\text { (Slovensko) }\end{array}$ & 45 & $180,6 \pm 5,0$ & $79,4 \pm 8,8$ & $24,3 \pm 6,9$ & $\begin{array}{c}11,9 \pm 3,2 \\
\text { (BIA) }\end{array}$ \\
\hline \multirow{3}{*}{$\begin{array}{l}\text { Soumar } \\
\text { \& Oberman } \\
(2010)\end{array}$} & $\begin{array}{c}\text { Vojáci } \\
\text { (bojové } \\
\text { jednotky) }\end{array}$ & 303 & $178,6 \pm 7,0$ & $83,0 \pm 10,3$ & $26,0 \pm 2,7$ & $\begin{array}{c}14,5 \pm 4,4 \\
\text { (Kožní řasy) }\end{array}$ \\
\hline & $\begin{array}{c}\text { Vojáci } \\
\text { (nebojové } \\
\text { jednotky) }\end{array}$ & 5964 & $179,3 \pm 6,3$ & $80,1 \pm 11,6$ & $24,9 \pm 3,1$ & $\begin{array}{c}13,5 \pm 4,3 \\
\text { (Kožní řasy) }\end{array}$ \\
\hline & $\begin{array}{c}\text { Vojáci } \\
\text { (základní } \\
\text { výcvik) }\end{array}$ & 1466 & $178,0 \pm 7,4$ & $76,8 \pm 11,1$ & $24,3 \pm 2,8$ & $\begin{array}{c}13,1 \pm 4,6 \\
\text { (Kožní řasy) }\end{array}$ \\
\hline $\begin{array}{l}\text { Komár } \\
(2012)\end{array}$ & $\begin{array}{l}\text { Studenti } \\
\text { UNOB }\end{array}$ & 40 & $178,7 \pm 6,9$ & $78,1 \pm 9,8$ & $24,5 \pm 2,8$ & $\begin{array}{c}12,9 \pm 3,9 \\
\text { (BIA) }\end{array}$ \\
\hline
\end{tabular}

Námi sledovaní probandi VO dosahovali ve srovnání s výsledky Maškové (2009) především nižších hodnot tělesné výšky (cm). Ve srovnání s výsledky Soumara \& Obermana (2010) a Komára (2012) dosahovali naši studenti VO i nižší tělesné hmotnosti $(\mathrm{kg})$ a nižších hodnot tělesného tuku (\%). Podle našeho názoru by tyto rozdíly mohly být způsobeny jednak odlišnou charakteristikou souboru, ale také použitou metodikou pro analýzu tělesného složení. Kohlíková (2009) uvádí, 
že u sportovců s dobře vyvinutým svalstvem hodnota BMI nevyjadřuje stupeň obezity, ale kvantitu svalové masy. V praxi je kromě BMI možné stanovit i WHR index (poměr pas/boky), který posuzuje rizikovost distribuce tělesného tuku. Oba indexy však nepodají podrobnou informaci o zastoupení jednotlivých komponent tělesného složení, proto se doporučuje použít některou z běžně dostupných př́istrojových metodik, např. BIA.

U sledovaného souboru studentů VO byl stanoven průměrný somatotyp charakterizovaný trojčíslím 1,7-7,3-2,5, tj. ektomorfní mezomorf, tj. jednoznačná převaha mezomorfní komponenty. Mezomorfní komponenta bývá označována jako rozhodující pro výkonnost (Pavlík, 1999). Endomorfní komponenta, která se podle Pavlíka (1999) ve vztahu k výkonnosti uvádí jako „brzdivý faktor“, byla u somatotypů studentů VO zastoupena velmi málo. Ektomorfní komponenta byla zastoupena u studentů VO více než endomorfní komponenta, což podporuje tvrzení Štěpničky (1979), který uvádí, že vyšší mezomorfní komponenta a nižší endomorfní komponenta se podílí značnou měrou na převaze $v$ motorické výkonnosti. $Z$ hlediska zjištěných hodnot byl průměrný somatotyp studentů VO morfologickým předpokladem k všestranné výkonnosti. Podle Pavlíka (1999) však vhodný somatotyp neznamená automaticky úspěšnost v některém sportu. K tomu jsou nutné další dispozice (např. psychické). Při porovnání s výsledky práce Kasala (2011), který jako ideální somatotyp pro plavce vojenského víceboje stanovil ektomorfního mezomorfa, by se tato disciplína jevila jako vhodná pro studenty VO. Pro krosový běh, který je také součástí vojenského víceboje, stanovil Picka (2011) stejný ideální somatotyp jako Kasal (2011), tedy ektomorfního mezomorfa. Podle Zvonaře a kol. (2011) je v případě běžců ektomorfní komponenta na vyšším stupni, nicméně dominující je mezomorfní komponenta. Podle Riegrové, Přidalové \& Ulbrichové (2006) jsou v této kategorii jedinci s velmi dobrými morfologickými předpoklady k všeobecné tělesné výkonnosti.

Co se týká analýzy tělesného složení, je třeba zdůraznit, že každá z jednotlivých komponent tělesného složení má svůj význam a při hodnocení naměřených hodnot je třeba přihlížet $\mathrm{k}$ individuální variabilitě každého jedince. Celková tělesná voda (TBW), která patří mezi jednu z nejvýznamnějších komponent složení těla, ovlivňuje především denzitu tukuprosté hmoty, ale tím i odhad tělesného tuku (\%). Průměrné hodnoty celkové tělesné vody (TBW) u sledovaného souboru byly $51,2 \pm 4,8 \mathrm{~kg}$, resp. $66,5 \pm 2,9 \%$, což můžeme hodnotit jako velice dobrou hydrataci. Průměrná hodnota $\mathrm{ICW}$ byla $33,9 \mathrm{~kg} \pm 4,10 \mathrm{~kg}$ a průměrná hodnota $\mathrm{ECW} 17,3 \pm 0,9 \mathrm{~kg}$. Uvedené hodnoty podporují tvrzení Riegrové a kol. (2010), která uvádí, že TBW představuje optimálně $60 \%$ tělesné hmotnosti, ECW kolem $20 \%$ tělesné hmotnosti a ICW přibližně $40 \%$ tělesné hmotnosti. Podle Rokyty (2000) tvoří nitrobuněčná tekutina (ICW) $66 \%$ veškeré TBW. Námi zjištěné průměrné hodnoty ICW dosahovaly $66,2 \%$. Komár (2012), který zjištoval vliv zkouškového období na kondici studentů Univerzity Obrany v Brně, uvádí průměrnou hodnotu TBW u studentů UNOB 60,3\%. Podle Gáby a kol. (2011) je celková tělesná voda výchozí proměnná pro stanovení tělesného složení prostřednictvím metody bioelektrické impedance. Ovlivňuje tedy i další tělesné frakce (např. množství tělesného tuku). Podle Bunce (2009) je adekvátní stav hydratace organismu podmínkou pro stanovení tělesného složení, kdy stav hydratace organismu může způsobit chybu o velikosti $2-4 \%$.

Metodika BIA neumožňuje rozlišení podkožního a strukturálního tuku, je možné zjistit jen celkové zastoupení tělesného tuku (\%) v organismu, případně množství viscerálního tuku či segmentární rozložení tuku. Je známo, že existují intersexuální rozdíly v množství a distribuci tělesného tuku. Tyto rozdíly jsou dány především hormonálně, muži ukládají více tuku do abdominální oblasti. Na množství a distribuci tělesného tuku se také v nemalé míře podílí i odlišná úroveň pohybové aktivity (Herland, Haarbo \& Christiansen, 1998). Množství tělesného tuku bylo u sledovaných jedinců v průměru $8,3 \pm 3,0 \%$, resp. $6,5 \pm 2,5 \mathrm{~kg}$, což v kontextu s charakterem somatotypu a dalšími parametry tělesného složení, např. množstvím TBW, můžeme považovat za poměrně nízké hodnoty. Nejvyšší zjištěnou hodnotnou tělesného tuku bylo 15,4%. Dlouhá $(1998,1999)$ zařazuje jedince s množstvím tělesného tuku v rozmezí 12-17\% do kategorie univerzitních sportovců. Podle Kutáče (2012) je srovnávání jednotlivých studií jen orientační a často problematic- 
ké, protože autoři řady vědeckých publikací se liší v horní hranici hodnot, které ještě považují za normové a poměrně často není ve studiích uváděn způsob realizace měření (např. použité přístroje, výzkumný vzorek aj.). Podle Gáby a kol. (2011) je z hlediska posuzování zdravotního rizika vzhledem $\mathrm{k}$ tělesnému tuku důležité měřit nejen jeho celkové zastoupení, ale i posoudit množství v jednotlivých segmentech. Při sledování rozložení tělesného tuku (\%) na horních končetinách jsme zaznamenali průměrné hodnoty na $\mathrm{PHK}=6,85 \pm 1,7 \%$ a na $\mathrm{LHK}=7,10 \pm 2,2 \%$, tj. průměrný rozdíl $0,25 \%$, rozdíl nebyl statisticky $\left(\mathrm{t}_{21}=1,161 ; \mathrm{p}>0,05\right)$ ani věcně $\left(\omega^{2}=0,02\right)$ významný. Na dolních končetinách jsme zaznamenali průměrné hodnoty na $\mathrm{PDK}=9,60 \pm 2,2 \%$ a na $\mathrm{LDK}=9,91 \pm 2,3 \mathrm{~kg}$, tj. průměrný rozdíl $0,31 \%$, rozdíl byl statisticky $\left(\mathrm{t}_{21}=2,071 ; \mathrm{p}<0,05\right)$ i věcně $\left(\omega^{2}=0,13\right)$ významný.

Množství tukuprosté hmoty bylo u sledovaných jedinců v průměru $70,5 \pm 6,1 \mathrm{~kg}$. Obecně se uvádí, že tukuprostá hmota je v lepším vztahu k úspěšnosti ve sportu (maximální aerobní výkon, čas běhu atd.) než množství tělesného tuku (\%). Ukazuje se, že množství tukuprosté hmoty má na rozdíl od celkové tělesné hmotnosti, tělesné výšky a dalších morfologických ukazatelů úzký vztah $\mathrm{k}$ různým funkčním veličinám jako např. spotřeba $\mathrm{O}_{2} \mathrm{v}$ klidu a při práci, minutový srdeční objem, objem cirkulující krve, respirační objem atd. (Pařízková, 1977).

Podle Skorocké, Bunce \& Kinkorové (2004) je ve sportovní praxi výhodné sledovat rozložení TBW v jednotlivých tělesných segmentech, kde se nerovnováha v zatěžování pravolevých polovin těla projeví nerovnováhou v distribuci tělesných komponent na těchto segmentech. Dále uvádí, že jednostranná preference končetin při tréninku a jednostranné zatěžování, může následně vést ke vzniku svalových dysbalancí a funkčních poruch pohybového systému. Podle Mahrové \& Bunce (2008) může řada pohybových aktivit působit na organismus jednostranně. Toto jednostranné zatížení a výskyt odchylek v držení těla můžeme odhalit vyšetřením pohybového systému (kineziologickým rozborem). Hodnocení metodou kineziologického rozboru je však značně subjektivní, proto je vhodné využít př́strojovou objektivizační metodu, která hodnotí tělesnou symetrii (např. BIA). Př́strojově jsme schopni zachytit i jemné odchylky při hodnocení svalové asymetrie. Při sledování rozložení svalové hmoty $(\mathrm{kg})$ na horních končetinách jsme zaznamenali průměrné hodnoty na $\mathrm{PHK}=4,34 \pm 0,5 \mathrm{~kg}$ a na $\mathrm{LHK}=4,26 \pm 0,5 \mathrm{~kg}$, tj. průměrný rozdíl $0,08 \mathrm{~kg}$, rozdíl byl statisticky $\left(\mathrm{t}_{21}=2,057 ; \mathrm{p}<0,05\right)$ i věcně $\left(\omega^{2}=0,13\right)$ významný. Na dolních končetinách jsme zaznamenali průměrné hodnoty na $\mathrm{PDK}=11,40 \pm 1,0 \mathrm{~kg}$ a na $\mathrm{LDK}=11,30 \pm 1,0 \mathrm{~kg}$, tj. průměrný rozdíl $0,1 \mathrm{~kg}$, rozdíl byl statisticky $\left(t_{21}=4,062 ; \mathrm{p}<0,05\right)$ i věcně $\left(\omega^{2}=0,40\right)$ významný. Kichul et al. (2001), Roche, Heymsfield \& Lohman (1996) ukazují, že zvýšený podíl tekutiny v daném segmentu je projevem vyššího zastoupení svalové hmoty v segmentu. Při hodnocení případných rozdílů $\mathrm{v}$ rozložení svalové hmoty, ale i tělesného tuku na jednotlivých segmentech musíme brát v úvahu především stranovou dominanci jedince, typ vykonávané pohybové aktivity, ale i např. úraz v anamnéze.

Tukuprostou hmotu (FFM) lze také popsat za využití molekulárního modelu jako součet mimobuněčné hmoty (ECM) a vnitrobuněčné hmoty $(\mathrm{BCM})$. Pro potřeby posouzení předpokladů pro pohybovou zátěž je rozhodující stanovení množství buněčné hmoty (BCM), která je částí tukuprosté hmoty (FFM) zahrnující metabolicky aktivní aerobní buňky kosterní a srdeční svaloviny, kostní tkáně a buňky vnitřních orgánů, patří mezi nejlepší ukazatele svalové činnosti, které mohou predikovat sportovní výkon (Andreoli et al., 2003; Bunc, 2009; Bunc \& Skalská, 2011). Mimobuněčná hmota (ECM) je tvořena součtem extracelulární tekutiny (ECW) a extracelulárních pevných látek (ECS). Z hlediska sportovního tréninku se jeví také velmi zajímavým parametrem poměr ECM/BCM, který představuje kvalitativní charakteristiku kosterního svalu (Talurri et al., 1999). Nesprávná výživa je charakterizována sníženou hodnotou BCM, naopak velkým zvýšením ECM a zároveň normálními hodnotami tukuprosté hmoty (Shizgal, 1987). Námi zvolená aparatura BIA (Tanita MC-980) stanovení tohoto poměru neumožňovala. 


\section{ZÁVĚRY}

V poslední době byl zaznamenán stoupající trend zájmu o hodnocení tělesného složení, resp. jeho jednotlivých komponent, a to nejen u jedinců z běžné populace, ale i specifických skupin populace (napřr. rekreační a vrcholoví sportovci). V př́íspěvku přinášíme výsledky měření vybraných antropometrických charakteristik, stanovení somatotypu a aktuálního tělesného složení u studentů Vojenského oboru (VO) UK FTVS v Praze a srovnání s obdobnými studiemi. Zjištěné výsledky průměrného somatotypu (1,7-7,3-2,5) spolu s vysokým podílem tukuprosté hmoty $(70,5 \pm 6,1 \mathrm{~kg})$ a nízké zastoupení tělesného tuku $(8,3 \pm 3,0 \%)$ poukazuji na velmi dobré předpoklady k všeobecné tělesné výkonnosti sledovaných jedinců.

Je třeba zdůraznit, že vzájemné vztahy jednotlivých tělesných parametrů jsou výrazně ovlivněny individuální variabilitou daného jedince. Můžeme se jednoznačně přiklonit $\mathrm{k}$ názorům, že nejen jednorázové, ale i opakované měření řady tělesných parametrů je významnou informací o prrípadném pozitivním či negativním vývoji každého jedince $\mathrm{z}$ nevojenské i vojenské populace.

\section{Literatura}

Andreoli, A., Melchiorri, G., Brozzi, M., Di Marco, A., Volpe, S. L., Garofano, P., Di Danikele, N. \& De Lorenzo, A. (2003) Effect of different sports on body cell mass in highly trained athletes. Acta diabetol., 40, 122-125.

Bláha, P. \& Vignerová, J. (1998) Percentilový graf BMI. Praha: SZÚ. Body mass index - BMI [online]. c2015, [cit. 2015-03-21]. Dostupné z www: http://www.euro.who.int/en/health-topics/disease-prevention/nutrition/a-healthy-lifestyle/body-mass-index-bmi

Bunc, V. (2006) Energetická náročnost pohybových aktivit a její využití pro ovlivňování tělesné hmotnosti. In Vobr, R. (ed). Disportare. České Budějovice: Pedagogická fakulta Jihočeské univerzity.

Bunc, V. (2007) Aktivní životní styl v biosociálním kontextu. Česká kinantropologie, 11 (3), 5-6.

Bunc, V. (2009) Tělesné složení u adolescentů jako indikátor aktivního životního stylu. Česká kinantropologie., 13 (3), 11-17.

Bunc, V. \& Skalská, M. (2011) Jsou předpoklady pro pohybové zatižení u osob s nadváhou nebo obezitou odlišné od osob s normální hmotností? Česká kinantropologie, 15 (3), 55-63.

Dlouhá, R., Heller, J., Bunc, V., Giampietro, M., Gambarara, D., Andreoli, A. \& Caldarone, G. (1998) Srovnání rovnic Pařízkové pro zjištování tělesného tuku sportujících žen. Med. Sport. Boh. Slov., 7 (1), 7-12.

Dlouhá, R. (1999) Výživa a složení těla. In. HAVLÍČKOVÁ, Ladislava. Fyziologie tělesné zátěže I: obecná část. 2. přeprac. vyd. Praha: Karolinum.

Ebner, Z. (2008) Vztah somatotypu a vybraných spirometrických parametrů u studentů a studentek Akademie ozbrojených sil v Liptovském Mikuláši. (Diplomová práce). Olomouc: Univerzita Palackého Olomouc, Fakulta tělesné kultury.

Gába, A, Přidalová, M., Válková, H., Walkley, J. \& Gábová, Z. (2011) Hodnocení tělesného složení u jedinců se středně těžkou mentální retardací. Česká antropologie, 61(1), 15-20.

Heath, B. \& Carter, J. E. L. (1967) A modified somatotype method. American Journal of Physical Anthropology. 27 (1), $57-74$.

Herland, M. L., Haarbo, J. \& Christiansen, C. (1998) Regional body composition determined by dual energy x-ray absorptiometry. Relation to trainung, sex hormones, and serum lipids in male long-distance runners. Scand J Med Sci Sports, 8, 102-108.

Hlúbik, P. \& Stř́tecká, H. (2007) Rizika poškození zdravotního stavu u př́slušníků Armády České republiky. Hygiena, 52 (3), 75-77.

Kasal, J. (2011) Sportovní trénink vojenského pětibojaře v plavání s překážkami a jeho specifika. (Bakalářská práce). Praha: Univerzita Karlova, Fakulta tělesné výchovy a sportu

Kichul, CH. et al. (2001) Evaluation of Segmental BIA for Measuring Muscle Distribution. Research thesis based on In Body. Biospace.

Kohlíková, E. (2009) Vybraná témata praktických cvičení z fyziologie člověka. 1. vyd. Praha: Karolinum.

Komár, A. (2012) Stravovací zvyklosti a výživový stav studentů Univerzity obrany, Vojenské rozhledy, 21 (53), 2, 120-136.

Kutáč, P. (2012) Vývoj somatických parametrů hráčů ledního hokeje. Česká antropologie, 62, (2), 9-14.

Mahrová, A. \& Bunc, V. (2008) Význam kompenzačních cvičení v prevenci a terapii svalových dysbalancí v tréninku badmintonistů. Studia kinanthropologica, 9 (2), 266-269.

Mašková, K. (2009) Stav tělesného složení u studentů a studentek 1. ročníku FTK UP na základě metody bioelektrické impedance. (Diplomová práce). Olomouc: Univerzita Palackého Olomouc, Fakulta tělesné kultury.

Pařízová, J. (1977) Body fat and physical fitness. Hague: Nijhoff.

Pavlík, J. (1999) Tělesná stavba jako faktor výkonnosti sportovce. 1. vyd. Brno: Masarykova univerzita.

Pavlík, V., Fajfrová, J., Husárová, M. \& Hlúbik, P. (2011) Prevence nadváhy a obezity v Armádě České republiky. Hygiena, 56 (3), 85-88. 
Picka, M. (2011) Sportovní trénink vojenského pětibojaře v krosovém běhu a jeho specifikace. (Bakalářská práce). Praha: Univerzita Karlova, Fakulta tělesné výchovy a sportu.

Riegerová, J., Přidalová, M. \& Ulbrichová, M. (2006) Aplikace fyzické antropologie v tělesné výchově a sportu: (příručka funkční antropologie). 3. vyd. Olomouc: Hanex.

Riegrová, J., Kapuš, O., Gába, A. \& Ščotka, D. (2010) Rozbor tělesného složení českých mužů ve věku 20 a 80 let (hodnocení tělesné výšky, hmotnosti, BMI, svalové a tukové frakce). Česká antropologie, 60 (1), 20-23.

Roche, A. F., Heymsfield, S. B. \& Lohman, T. G. (1996) Human body composition. Champaign: Human Kinetics.

Rokyta, R. (2000) Fyziologie pro bakalářská studia v medicíně, př́rodovědných a tělovýchovných oborech. Vyd. 1. Praha: ISV.

Shizgal, H. M. (1987) Nutritional assessment with body composition measurements. J Parenter Enteral Nutr., 11(5), 42-47.

Sigmundová, D. \& Sigmund, E. (2012) Statistická a věcná významnost a použití koeficientů velikosti účinku při hodnocení dat o pohybové aktivitě. Tělesná kultura, 35 (1), 55-72.

Skorocká, I., Bunc, V. \& Kinkorová, I. (2004) Určení distribuce tělesných tekutin př́ístrojem In Body 3.0. Česká kinantropologie, $8(2), 19-25$.

Soumar, L., Bolek, E. \& Stejskal, P. (2008) Vybrané parametry aktuálního stavu vojáků - porovnání bojových a nebojových jednotek. In Sborník Mezinárodní vědecké konference Zvládání extrémních situací. Praha: CASRI, 123-131.

Soumar, L. \& Oberman, Č. (2010) Dlouhodobé monitorování aktuálního tělesného stavu populace s důrazem na příslušníky Armády České republiky. Vojenské rozhledy. 4, 174-189.

Střítecká, H. \& Hlúbik, P. (2009) Program rozšířené prevence Armády České republiky. Hygiena, 54 (4), 117-121.

Štěpnička, J. (1979) Somatické předpoklady ke studiu tělesné výchovy. Vyd. 1. Praha: Univerzita Karlova.

Talluri, T., Lietdke, R. J., Evangelisti, A., Talluri, J. \& Maggia, G. (1999) Fat-free mass qualitative assessment with bioelectric impedance analysis (BIA). Ann N Y Acad Sci., 20 (873), 94-98.

Wei, M., Kampert, J. B., Barlow, C.E., Nichaman, M.Z., Gibbons, L.W., Paffenbarger, R.S. \& Blair, S.N. (1999) Relationship between low cardiorespiratory fitness and mortality in normal-weight, overweight and obese men. Journal of the American Medical Association. 282, 1547-1553.

Zvonař, M. \& Duvač, I. (2011) Antropomotorika pro magisterský program tělesná výchova a sport. 1. vyd. Brno: Masarykova univerzita. 